\title{
A bad name is an omen: Stigmatising names amongst the Basotho
}

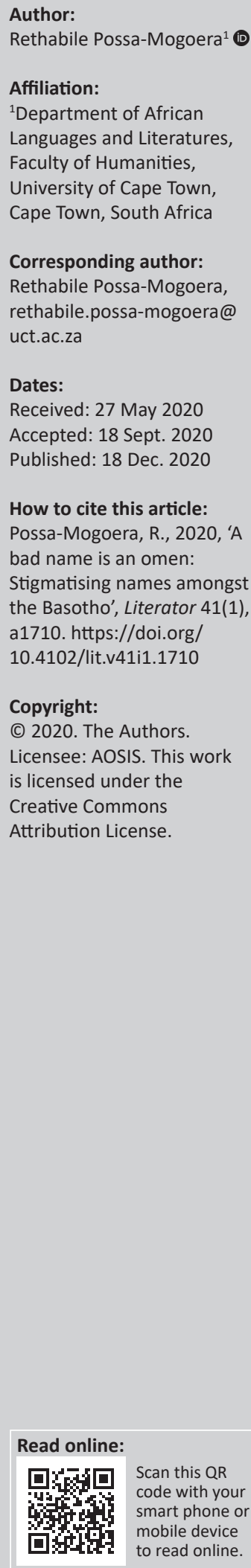

This study questions the existence of the proverb Lebitso lebe ke seromo [A bad name is an omen], which has been used by Basotho from time immemorial. This proverb shows that giving a child a bad name is a disadvantage to the child; however, Basotho named and continue to give children unpleasant names. These names stigmatise the name bearers and make one feel unwanted and detested by the family and the society they belong to. The result of this is a bitter, unsympathetic, insensitive and self-centred child. The question is whether Basotho's intentions when formulating this proverb were to curse the name bearers or the so-called illegitimate children who are given these names, or to conscientise the name givers to be careful when naming children. This emanates from the fact that they know very well how a bad name affects the bearer. The researcher has been collecting and documenting these names from 2010 to date. This article aims to discuss the different names given to the so-called illegitimate child, abandoned, rejected and unwelcome children, as they are the ones who are mostly given these bad names. This article further investigates the reasons why these names were given to the child and who named the child. The effect these names have on their bearer and the behaviour resulting from such names will be discussed. This article will finally challenge the proverb Lebitso lebe ke seromo. This study will adopt onomastics and discourse analysis to analyse and interpret data.

Keywords: proverbs; naming; discourse analysis; onomastics; illegitimate child; Basotho; Lebitso lebe ke seromo; critical discourse analysis.

\section{Introduction}

One's name is supposed to be music to one's ears and knowing and calling one by name reveals the importance of one to the society as a unique and valuable individual. A name is one way of registering existence in the country, in the village, in the workplace and in the family. This then suggests that it must be a good name, a meaningful one, and one appreciated and understood by the society as well as the name bearer.

Tullock (1993:40) explains a name as 'the word by which an individual person, animal, or thing is known or spoken of'. Similarly, Sogoba (2019:1) posits that a name can shape a person's character, mould their social identity and even influence their destiny. The meaning attached to a name will determine much about the present and the future of a child. One can often infer someone's sociocultural aspects from their name: their ethnicity, their gender, and also their day or date of birth, their family's occupation, their social and political class, the religion and deities they follow, the hopes and dreams of their parents, etc. It can also express the values, ethics and beliefs of the culture they are born into.

\section{Through his observation Agyekum (2006) declares that:}

$[A]$ name creates an expectation and an attitude in those that hear it, even before they meet the namebearer. This is partly why, when introduced to people of different ethnic groups, many West Africans will not only say their name, but explain its meaning, so that it is clearly understood regardless of language barriers. (p. 206)

This means a name is a word by which something or someone is known, and naming a human being has proved to be the most important event in that person's life. This name is believed to mould or shape the name bearer until death.

\section{According to Letsoela (2015):}

[N]aming is not just an act of linguistic labelling by which speakers of a language identify the entities they are referring to in the real or imaginary world. A name is not chosen arbitrarily but is chosen based on a 
combination of socio-cultural factors. This is because language cannot be divorced from culture, for it is through language that speakers reflect their cultural and sociolinguistic etiquette. (p. 1)

\section{Naming amongst Basotho}

Guma (2001:267) maintains that naming in Sesotho is both a cultural and linguistic phenomenon. The meaning attached to names by Basotho plays a significant role in the definition of 'personhood' because it is believed that a given name does not only serve as an identity but also determines the type of person the individual will be. He further observes that names are believed to have influence on the character of the bearer and there is a proverb that refers to the influence of names on character: Lebitso lebe ke seromo (literally, 'a bad name is an omen'). The names given to individuals refer to historical events, experiences, emotions, status relations, clan and kinship relations, as well as authority.

According to Possa and Khotso (2015:36), a name amongst Basotho is believed to be of vital importance. In most cases, Basotho believe that a name has power to influence a situation or that anyone or anything takes after its name: be it a person, plant or animal; hence, they have proverbs like lebitso lebe ke seromo [A bad name is an omen]. Guma (2001:267) testifies that naming is an important process carried out in Basotho families. This process is carried out by the elders of the families and they are expected to name newly born babies as well as newly married women. In both cases, the decision of which name to give to the baby and the married woman lies entirely with the elders of the family, both males and females.

Letsoela (2015) notes that Matee (2006) examined the Sesotho personal names with a view to unveiling the significance of such names. Matee learnt that Sesotho personal names reflect circumstances, experiences and events that surround the birth of the name bearer. She also observed that in the Basotho society, a name is not just given for the sake of naming' (Matee 2006:22). Mokhathi-Mbhele (2006) also studied Sesotho personal names. She observed that whilst the names convey important sociocultural information, they are analysable into syntactic components such as phrase types and sentence types (Letsoela 2015:2).

In naming a child, Basotho did not just pick up a name because they like it but they had to pick up a name based on the circumstances or for a certain purpose or naming after someone. The belief has always been that when the child grows up, it might act according to its name; the saying lebitso lebe ke seromo [a bad name is an omen] reflects this attitude. This means naming practice has always been important and the name is only given after a thorough consideration.

According to Mbiti (1990) in Mabunda (2012:34):

[C]orrectly that almost all African names have meanings rooted in culture and history. Names bestow identity. A name has an impact on the life of an individual and his or her family. (p. 115)
The naming of children is an important occasion that is often marked by ceremonies in many African societies. In many societies, it is still a common custom to name children after their grandparents or the deceased. The use of traditional names is believed to tighten the family bonds and remember those who have departed. It is important to give a child a traditional name because of the belief that the name would guide and protect the life of the child. It is also believed that the child will take after the person he or she is named after.

The above statements confirm that Basotho stigmatising names are not random names. From what Mbiti says, these names like other names have meanings or are related to events that transpired when these children were born.

\section{Who are name givers?}

The elders normally follow a certain traditional criterion to give names. They can name a child after people, as a result of a happening or just a name that can be found appropriate.

Sengani (2008) in Mahwasane and Tshifaro (2019:175) 'reiterates that the elders/seniors in the family have the privilege of bestowing names on children as they are regarded as having a wealth of knowledge on heritage and customs'.

Arno (1994:25) points out that 'in many communities, naming children has always been the prerogative of the elders'. Sengani (2015) believes that:

This is because they are seen to have the knowledge and skill to create or record history. As the appointed custodians of culture and heritage, they remind people of events that took place in the past and in the present, and project into the future. (p. 1)

For this reason, Akinnaso (1980:279-280) in Sengani (2015:3) declares that the names tend to relate to the environment, history, politics, economy and events within the community. Traditionally, children are named by specific people only, such as the elders or medicine men or women and grandmothers. They are regarded as having the social power and capacity to impose constraints on the younger people's behaviour and thoughts to subject them to the elders. These customs are not violently or overtly imposed but are legitimised through proverbial sayings that are grounded in the authorial language of the elders. They and they alone have privileged access to valued resources, such as the knowledge surrounding naming.

\section{Naming after someone}

Mönnig (1967:338) in Guma (2001:276) asserts that 'naming a child after kinsmen serves a religious, political, and social function'. Similarly, Guma quotes Mohome (1972) who maintains that the system amongst Basotho of naming children after their paternal or maternal relatives serves to perpetuate the names of ancestors, and it brings grandparents and grandchildren closer to one another. Alternate 
generations of grandparents and grandchildren are linked together. It is also believed that the child so named will inherit the virtues of his grandparents. Religiously, to honour ancestral forces for their influence upon the living, a child is named after one of them (Guma 2001:267).

Setiloane (1975:34) in Guma (2001) maintains that according to Basotho, 'children are a gift of badimo' (ancestors):

[F]ailure to conceive is attributed primarily to the disfavour of badimo. Thus, a child who has been born a long period after the mother has been married is named Mpho [gift], Keneiloe [I have been given], and Kelebogile [I am grateful]. This ancestral relationship is also epitomized by such personal names as Oatile. (p. 267)

Furthermore, Mohome (1972:172) in Guma (2001:268) observes that: 'children can also be named after a prominent or famous person, or a neighbour, or after a midwife if the child is a girl.'

This article investigates how the so-called illegitimate, abandoned, rejected and unwelcomed children are named in Basotho culture and how this practice of naming children impacts on them. The application of the proverb lebitso lebe ke seromo is interrogated too. This is done by looking at the types of names given, and message embedded in the given names and the name givers. It argues that Basotho use their power to ridicule, humiliate and voice their dissatisfaction through naming. And names given to these children force the concerned children into difficult situations.

\section{Research methodology}

The researcher uses the qualitative approach for this research. Creswell (1994) defines the qualitative approach as:

$[A] n$ enquiry process of understanding a social or human problem, based on building a complex, holistic picture, formed with words, reporting detailed views of informants, and conducted in a natural setting. (p. 38)

The researcher chose this approach because it allowed her to use interviews and observation techniques for data collection. Babbie (1992:6) supports the use of more than one method when she confirms that 'the best study is one that uses more than one research method, taking advantage of their different strengths'.

The interview method is very important because it is 'often the primary source of data during a qualitative research approach' (Babbie 1992:6). Data were collected through unstructured interviews so that the researcher could get more information from the participant. Participants were 120 individuals, some of them had the names in question. The researcher obtained consent from the participant to audiorecord some of the interviews. Telephonic interviews were also conducted for those participants who were not physically available. Observations were made involving different people bearing these stigmatising names.

\section{Theoretical framework}

This article employed a sociolinguistic-onomastic theoretical base and discourse analysis.

The use of interdisciplinary theory is in order because onomastics is a theory that allows the use of other theories. Principles and methodologies of onomastics were employed for the present investigation of Basotho naming as it seeks to understand the history, culture and philosophy of the Basotho about their naming.

\section{According to Coates (2013):}

$[O]$ nomastics is the discipline which seeks to answer the semasiological question 'Why is X called X?' This fundamental question may be understood in two ways: as a linguistic and historical one, 'Why and how did X come to be called X?', and as essentially a historical or cultural one, 'What does it mean for $X$ to be called X?' (p. 1)

Coates further indicates that 'onomastics is a specialised branch of etymology, with which it shares its methods, but the second looks it into wider concerns about human history and conventions'. He explains that the 'answers to these questions typically intertwine, since knowledge of a proper name's origin may be part of its present cultural meaning' (Coates 2013:1).

Possa and Khotso (2015:37) indicate that naming displays historical, cultural and social disciplines, and as a result, names can be analysed using a mixture of theories. Neethling (2005:2) asserts that names fall within the category of linguistic signs. This means that names could be investigated from a linguistic perspective as well. Moreover, the article intends to find the sociocultural meaning of these names. This is because names have a connection with the society which uses them.

In this study, the language or discourse will be used to express the baby naming practices that are deeply rooted in the social, cultural, environmental and political influences of the Basotho people. According to Blommaert and Bulcaen (2000):

[C]ritical Discourse Analysis emerged in the late 1980s as a practical development in European discourse studies spearheaded by popular scholars such as Norman Fairclough, Ruth Wodak, Teun van Dijk and others. (p. 448)

Van Dijk (2001) maintains that:

$\mathrm{CDA}$ is a type of discourse analytical research that primarily studies the way social power abuse, dominance, and inequality are enacted, reproduced and resisted by text and talk in the social and political context. (p. 96)

Similarly, Blommaert (2005 cited in Sengani 2015:4) points out that: 'CDA looks at how language is used by the powerful social group to oppress the powerless, which in the end empowers the oppressed or powerless social group'. 


\section{Sengani (2015) stated that:}

$[P]$ ower relations everywhere shape the use of language as the elderly name their grandchildren. CDA is said to be biased towards the underdogs as they are the ones who are dominated, controlled, abused and suffer the inequalities. (p. 5)

These theories will help the researcher to analyse stigmatising names given to children.

\section{Analysis}

In this section, data will be categorised into different headings and analysed.

It has been indicated earlier in this article that Basotho used names to do so many things. The mother-in-law would express her dissatisfaction by giving a child the name that passes the message to the daughter-in-law. If the husband does not trust that the child is his, he would tell his mother and the mother would question the woman about the father through the name given to that child. The accusations or dissatisfaction against the sister-in-law were demonstrated through the baby naming practice.

This section will show such names that are among derogatory and stigmatising, which are mostly common among illegitimate children.

\section{Illegitimate child}

According to Hanafy (2016:482), 'Illegitimate children were unwelcomed, ostracized, often abandoned (sometimes in church-based protective institutions) or killed by their mothers'.

Thipa (1984) in Sengani (2015:3) refers to such cases as 'rocking the boat, where children who are illegitimate are given names that are a constant reminder to their parents of their family circumstances'. Thipa mentions names such as Sebueng, meaning 'Don't say anything', Nthofela, meaning 'A mere thing'. Thipa confirms that these names are a constant reminder of what the parents did and, at the same time, speak indirectly to the children, and unfairly so.

The names below question the mother about the child's father.

1. Rebokamang? (Whom do we praise?). This name giver was the paternal grandmother to a male child. Amongst the Basotho and other African societies, giving birth to a baby boy is such an honour. The belief is that when a son is born, the family will grow because the son will marry, and his wife will bear sons who will keep the family growing even more. In this case, when a boy is born, his father is praised by the members of the family. However, in the name Rebokamang? (whom do we praise?), which is a question to the mother, an answer is demanded by the family members as to who the father is because they believe that the present father does not deserve the praise as he is not the father. This name is intended to humiliate the mother.

2. Moramang? (Whose son?). This name giver was the paternal grandmother to a male child. In this name, the question is directed to the mother by the elders of the family, as well as the husband in some cases. They demand an answer about whose son the child is because they believe he is not of their blood. Amongst the Basotho, knowing one's father is of great importance especially for a male because it allows the family members to perform relevant customs to the concerned child. In the case where these rituals are not performed, it is believed that the child may not be successful or may be despised by others or even die, hence it is important to know and understand one's roots. It is also very important to carry a father's name as it makes one feel accepted into the family. The name Moramang? (Whose son?) indicates that nobody knows who the father of the child is, so the mother is requested to tell who the father is so that the rituals can be performed for the child which correspond to his own identity. Because of this name, the child grows up being haunted by the question of who the father is and questions the mother. In most cases the child ends up hating himself, the mother and everybody in that family. This name is also intended to humiliate the so-called cheating mother.

3. Motsekae? (Which village does the father come from?). The name giver was the paternal grandmother to a male child. Basotho have different villages that identify with a certain surname. It is common for people with the same surname to live in one village. But it could also happen that non-related members lived in the same village. So this could be a potential father to the child born in this family. So if the family does not believe that he belongs to that family and village, a question is posed to the mother, Motsekae? (Which village does the father come from)? This family believes that the father of the child does not belong to this family and the mother is expected to tell the real village of the father of the child. The child will also in return demand to know why he was given such a name and he will demand an answer from the mother. This makes a child an outcast and humiliates the mother.

4. Tsoakae? (Where from?). The name giver was the paternal grandmother to a female child. This name is usually given to a child in the case where the parents were not together for some time because of work-related issues or family conflicts and during this separation the woman conceives. The family members always assume that the child does not belong to their family as their son was not there at the time of baby-making, although this is not always the case as the possibility is that the woman conceived just before the separation. For this reason, the mother is requested to tell them where she got the child. This name normally causes conflict between the father and the mother as it works as an eye-opener to the father who also develops doubts about the baby. This name humiliates the mother. 
5. Rebotsa mang? (Whom do we ask?). The name giver was the paternal grandmother to a male child. Every Mosotho has a clan that identifies him or her in relation to others. Basotho believe that a clan is very important to the child. This is the reason why in Sesotho when a child cries, the mother calls that child with his or her clan. This clan is associated with the ancestors; calling one's clan is calling one's ancestors to soothe the child. In the case where the child does not stop crying, the mother is normally advised by elderly women to go out in privacy and call the child with his or her real father's name (clan). Similarly, when a boy has gone to initiation school, it is very important to know his clan as it will be used to invite his ancestors to be present in the whole process. It is therefore very important to know one's clan. In this name, the mother is expected to give direction as to whom should be asked concerning the child's clan. The child will also want to know what his real clan is because the one that he will be using will be believed not to be his.

6. Haretsebe (We do not know). The name giver was the maternal grandmother and grandfather to a male child. This name is given to the child who is born out of wedlock. Having a child out of wedlock is still a bitter pill to swallow amongst Basotho. They believe that their upbringing was flawed, and they get so angry and believe their daughter has humiliated them. The mother would be questioned who the father is and if she says she does not know, her parents named her child Haretsebe.

7. Harejoetsoe (We are not being told). The name giver was the paternal grandmother to a male child. If they suspect that the child does not belong to the family, they start questioning the mother to the extent that when that child is born, they give it the name Harejoetsoe (We are not to be told). They demand to be told who the father is. In the same manner, this name leaves a big question mark over the child concerned. What is it that these people want to be told? What is it that I must be told? The mother is therefore left in a tight corner of telling who the father of the child is.

\section{Names that suggest that the child is unwelcomed}

There are children who are born in marriages but whose fathers feel like their mothers were not loyal and they may not be the real fathers. These children bear names that show they are not wanted or welcomed into such families. Here is the list of such names:

8. Liphapang (Conflicts). The name giver was the paternal grandmother to a male child. This name suggests that this child has brought nothing but conflicts in the family. In most cases, the father and the mother do not see eye to eye because of the pregnancy until the baby is born. There is nothing positive that shows this child is welcomed into this family. This is because the husband was not ready to have a child or has no feelings for the mother anymore.

9. Bothata (Problem). The name giver was the paternal grandmother to a male child. This name is also given to the child who is born from two fighting parents. The child is not welcomed with happy hands because he is born into an unhappy family and it is believed this pregnancy caused more problems.

10. Likhupiso (Annoyance). The name giver was the paternal grandmother to a female child. This name is similar to names in 8 and 9. The baby is not welcomed as she is believed to bring more frustrations into the family.

11. Nthoesele (Nonsense). The name giver was the paternal grandmother to a female child. In many cases, this name is given to the child that comes after two or more girls as the family wants a boy child. This child is not welcomed because the father wanted a male child but birth was given to a girl.

\section{Names indicating that the father rejected the child}

12. Mohanuoa (The rejected one). The name giver was the paternal grandmother to a male child. This name shows that the child was not accepted but rejected by the family. This name is usually given to children whose mothers do not see eye to eye with their in-laws. They use the name to express their feeling towards their daughter-in-law.

13. Nkhanuoa (The rejected one). The name giver was the paternal grandmother to a male child. This name is like the one in 12 above showing that the child is rejected or denied being part of the family.

\section{Names signifying the location where the child was conceived}

The names below are given to the children born out of wedlock. It is believed that they were conceived out in the bush or thorns because they were not planned in the houses or at homes:

14. Matlakala (Garbage). The name giver was the maternal grandmother and grandfather to a male child. This name indicates that the child was conceived in the dirt. This name suggests that the child is not worth anything good because of how it was conceived. The child bears this name and must live with it for the rest of his life.

15. Mathonako (Picked up on the street). The name giver was the maternal grandmother and grandfather to a female child. This name is given to girls who are born out of wedlock. The parents take out their anger on the child by giving her this bad name. It shows the child was not planned at home but out in the street.

16. Makgokolotso (The one who had been gathered on the street). The name giver was the maternal grandmother and grandfather to a female child. This name, like Mathonako, indicates that the child was not planned as the mother conceived her out of wedlock.

17. Mohlabaneng (The place where people relieve themselves). The name giver was the maternal grandmother and grandfather to a male child. Mohlabana is where people who do not have toilets at home go to. It is a very disgusting, stinking place. Even people who use it find it very unpleasant, but circumstances force them to use it. This also shows the anger and frustrations of the parents and they give the child this name in order to reprimand and humiliate the mother. 
18. Dihlahleng (In the bush). The name giver was the paternal grandmother to a male child. This name is like other names under this category. It shows that the child was unplanned and was conceived in the bush.

\section{Names showing surprises or doubts about the child}

19. Remaketse, Dimakatso and Seipati (We are shocked and the hidden one). These are the names given by the maternal grandmother. These names are usually given when a pregnant girl hid the baby until the day of delivery.

20. Pelaelo (We have doubts). This name is given to children whom the alleged father has doubt about, in terms of whether the child belongs to him or not.

21. Dimakatso, Mmakading and Ntsotiseng (We are shocked/Join me in this shock). These are the names given by the maternal grandmother. Similarly to Remaketse, this name is given to the child whose mother hit the pregnancy until the day of delivery.

\section{Names showing that the child was abandoned after birth}

According to Hanafy (2016):

[C]hild neglect is not a new phenomenon. It has existed since the beginnings of recorded history. Child maltreatment has for a long time been recorded in literature, art, and science in many parts of the world. Infanticide, exposure, and abandonment date back to ancient civilizations. (p. 482)

Similarly, there were children who have been given for adoption or left unattended after birth. Basotho have the same experience too. There are children who will be found abandoned on the streets or dumping sites. These children are the ones who are given these names:

22. Kherehloa or Molahluoa (abandon) is a child whose father has run away whilst the mother is pregnant and left the child with grandparents. This incident mostly happens to couples who were engaged and the engagement breaks off.

Unfortunately, the name bearers of these names grow up knowing they were abandoned and do not belong to the family they live with. These names are their constant reminders that they were not wanted by their biological parents.

\section{Names ridiculing the mother}

Names under this category are usually given to the so-called illegitimate child. Having a child out of wedlock was such a disgrace to the family of a girl who fell pregnant. Parents would be so ashamed as it was believed that they failed in their upbringing. This was so hectic that some parents would even disown their daughters who fell pregnant. Parents would warn their daughters against the ones who fell pregnant and tell them to stay away from them. Others would laugh at their parents and use them as a bad example to other children. The pregnant girl would be isolated from everyone because of the stigma of being pregnant before marriage and this will extend to the child she will give birth to. Below is the list of names ridiculing the mother.

23. Ditshenyeho or Mosenyehi (The rotten/spoiled one). The name giver was the maternal grandmother and grandfather to a female child. When a girl conceived out of wedlock, the Sesotho term used is ho senyeha (to be spoiled). This shows how bad it is to fall pregnant out of wedlock. The name Ditshenyeho is therefore derived from ho senyeha. Anyone who hears this name knows that the bearer of the name is either born out of wedlock or has been named after someone. However, people usually choose to go with the bad one of being born out of wedlock.

\section{The voices of the name bearers}

This section will discuss and share the views of the name bearers and mothers.

When interviewing the respondent Ditshenyeho (The rotten/spoiled one), she indicated that her mother had her when she was 17 and still at school, so that is why her grandmother gave her this name. She said how she was treated at school and at the village was because of her name; she resented her mother and blamed her for being mocked and bullied. She said that other learners would use her name to get at her and she lost confidence and became ashamed of herself. She said they would say she is a useless one because she was given that name and her family clearly did not want her. She stated that at one stage she wanted to change her name but could not because her certificates were in this name. She said she has anger issues which she blames on her name.

Dihlahleng (In the bush). The bearer of this name did not want to be interviewed but told the researcher that he loves his name because he has never heard anyone called by this name. When asked whether he knows what it means, he said he was not interested in what it meant because he was named by his grandmother.

Matlakala (Garbage). The respondent said he was given this name by his maternal grandmother. He was named after his uncle. He said he hates this name because it tortured him so much. He indicated that many people from his childhood were making fun of him even today. He thought of changing this name but could not. He felt a need to keep it because it was his uncle's and he was told that he would be punished by ancestors if he changed it. During the interview, the respondent indicated that he is 48 years old but has not achieved anything in life. He blames it all on the bad name he was given by his grandmother. He indicated that growing up, he was treated like trash as his name denotes. He said he spent most of his life in prison and this is the only place he felt confortable because he was not judged. When asked whether he could give his child a derogatory name, he said 
he would never do that as he saw what a name can do to a human being. He believes this proverb lebitso lebe ke seromo is the truth because when he looks at his life, he thinks it is in line with his name.

Nkhanuwa (The rejected one). The respondents here were the mother and the name bearer. The mother indicated that her mother-in-law never liked her and wanted his son to marry someone else, but the son followed his heart and married her. When the child was born, she named the child Nkganuwa, meaning she did not approve of the child too. The mother told the researcher that this broke her heart but there was nothing she could do but to obey her in-laws. However, when the marriage failed, she changed her daughter's name to Nkgopoleng (Remember me). This name still carried a message to her in-laws, but she feels like it was much better than Nkganuwa. When interviewing the name bearer, she said she hates both the names and feels like she was being used as a bait by both her mother and her grandmother. But she hated Nkganuwa more and never used it when she went to school. She felt embarrassed every time she was asked what her name was.

Nthoesele (Nonsense). The respondent said she was named after her aunt who passed on. She said her aunt was the third of the five girls, so she was named Nthoesele. Then coincidentally, the same thing happened to her as she was the fourth of the girls, and like her aunt, she was named Nthoesele. She said her life has been miserable because of this name. When narrating her story, she said, when growing up, the incident that she will never forget is the one done by the principal. She said he would call her nthoesele ya ngwana (a rubbish child) in front of other learners and they would make fun of her. She says everyone called her Rubbish because of the principal. She said she ended up dropping at school but to date her parents do not know why she hated school. She believes that she could have been educated like her other sisters if she was never bullied or given this name. She said that there were times when she wanted to change it, but her family convinced her that she must not change as it belonged to her late aunt. She said she would never name her children like this because the child is punished for what they do not know.

Tsoakae? (Where from?) was given this name by her paternal grandmother. The respondents here were the mother and the daughter. The mother maintained that as a daughter-in-law, she was told that her daughter must take her aunt's name. As this was their culture, she had to abide by this instruction. The mother was not happy with this name and she wanted to change it when her daughter went to school. She said her fear was that her daughter will be discriminated against and questioned about her existence. She said the name was demeaning and discriminatory. The name bearer said that she has been questioned about where she comes from. She said she has been explaining herself to an extent that she is tired, and she really hates her name.

\section{Discussion}

This study exposed how the baby naming practice discourse creates power play and control between the mother-in-law and daughter-in-law and maternal parents and daughters. Mahwasane and Tshifaro (2019:175) argue that 'names were channels through which people could express utterances which are a message whose sender is the name giver'. Sengani (2015:08) supports this when he says, 'although names are usually used to refer to children and provoke their response', it is the elders and the children's parents who are speaking to each other. In doing this, they create hidden voices and identities around the name-carriers who are blameless or innocent children. At an underlying level, the negative image or identity created belongs to the elders and the parents, but also affects the children. Through these names, the parents express power, although indirectly, and take on the elders in the battle over the surface identities of the children, but really intend taking on the underlying ideologies which paint them negatively. It was noted that in such cases, as children who are the name-carriers feel burdened by the names, the parents replace or shorten them in order to create positive identities.

The analysis demonstrated that there has been misuse of power when naming children. We saw names ridiculing the mother, showing location of where they were convinced and showing that they were not welcomed into the family. In most instances, the parents of these children were forced to accept these names because of being powerless when it comes to naming of children. Sengani (2008) in Mahwasane and Tshifaro (2019:175) reiterates that the elders/seniors in the family have the privilege of bestowing names on children as they are regarded as having a wealth of knowledge on heritage and customs'. Sengani (2015:3) says, 'this means that even if a name is insulting or creates an ugly identity, it should be accepted because it was given by experts'.

Mahwasane and Tshifaro (2019:175), however, observe that:

$[T]$ he paternal grandparents and other senior members, as custodians of culture, are vested with the power to name newborn babies, they convey inherent communicative messages through these names, such as mocking, scolding and instigating conflicts which tend to cause heated discourse that becomes a battlefield for the name-givers and addressees. (p. 175)

The study found the psychological impact that these name bearer deal with because of these names. Some blame their failure on the names they were given arguing that even the proverb under scrutiny lebitso lebe ke seromo justifies that a bad name is an omen. The question is why Basotho would continue to name or give their children bad names when they know very well that a bad name follows the name bearer and it can even shape their life or behaviour. Some name bearers have not made it in life and their mental health status is not pleasant and they are so angry with their mothers who allowed their grandmothers to give them such names. They believe they could be better people with a stable life and income. 
Naming children after their elders and giving them stigmatising names should come to an end as it impacts negatively on the innocent children. Besides, there is no justification for giving children malicious names that put them in a bad situation where they must answer to why they have such names. Many children are being harassed by others at schools because of the names they have been given. Some try to explain that they were named after someone, but it is always useless.

This research found out that this malicious naming practice is not only prevalent amongst the Basotho but exists in other African cultures. Mahwasane and Tshifaro (2019:182) maintain that the younger generation therefore feels that they want to resist the power abuse and domination of the elders of the family by bestowing names on their babies themselves. Furthermore, this study uncovered how the baby naming practice discourse produces power play and domination between the older generation and the younger generation. The elders who were name givers used the naming practice to communicate crucial cultural information to members of the family, be it positive or negative, pleasant or unpleasant. In most cases, the elders would use this baby naming practice to mock, chastise and even relate stories about the different generations, including the departed members of the family. Their daughters-in-law were no exception to this modus operandi.

Basotho respondents confirm that these names impact on the bearer's life and most of the time have painful consequences that the bearers have to endure.

The research as it was informed by the critical discourse analysis shows that paternal grandmother and maternal grandparents used their position of power to express their dissatisfaction with their daughters-in-law and daughter's attitude towards them. They expressed their dissatisfaction through naming, and this put the daughters-in-law and the daughters under the powerless social group. In the whole process, the victim being the innocent child.

\section{Conclusion}

This research was questioning the proverb lebitso lebe ke seromo that shows Basotho were very much aware that giving a child a bad name can result in that child having multiple problems. The study proved that this proverb is true. The respondents indicated that their names followed them in life. They indicated that they believe if they had been given proper names, their lives could have been different. The finding truly confirmed that most of the names given to children were not welcomed by the parents because of their messages but because they could not argue or question the elders, they kept such names for their children. Some were afraid of their parents because of the stigma that came with having a child out of wedlock. So, their children had to carry that burden of informing everyone that they were born out of wedlock.

\section{Recommendations}

It is recommended that these stigmatising names should be banned amongst Africans. Parents should also be given the rights to name their children in order to avoid bad names being given to their children by the in-laws.

\section{Acknowledgements}

Special thanks for all who gave me an opportunity to interview them. This is much appreciated.

\section{Competing interests}

The author has declared that no competing interest exists.

\section{Author's contributions}

R.P-M. is the sole author of this research article.

\section{Ethical consideration}

The author confirms that the data supporting the findings of this study are available within the article.

\section{Funding information}

This research received no specific grant from any funding agency in the public, commercial or not-for-profit sectors.

\section{Data availability statement}

The author confirms that the data supporting the findings of this study are available within the article.

\section{Disclaimer}

The views and opinions expressed in this article are those of the author and do not necessarily reflect the official policy or position of any affiliated agency of the author.

\section{References}

Agyekum, K., 2006, 'The sociolinguistic of Akan personal names', Nordic Journal of African Studies 15(2), 206-235.

Akinnaso, F.N., 1980, 'The sociolinguistic basis of Yoruba personal names', Anthropological Linguistics 22(7), 275-304.

Arno, A., 1994, 'Personal names as narrative in Fiji: Politics of the luana onomasticon', Ethnology 33(1), 21-34. https://doi.org/10.2307/3773972

Babbie, E., 1992, The practice of social research, 6th edn., Wadsworth, Belmont, CA. Blommaert, J., 2005, Discourse, Cambridge University Press, Cambridge.

Blommaert, J. \& Bulcaen, C., 2000, 'Critical discourse analysis', Annual Review of Anthropology 29, 447-466. https://doi.org/10.1146/annurev.anthro.29.1.447

Coates, R. (ed.), 2013, The encyclopedia of applied linguistics, Blackwell Publishing Ltd, Chapelle.

Creswell, J.W., 1994, Research design, Sage, Thousand Oaks, CA.

Guma, M., 2001, 'The cultural meaning of names among Basotho of Southern Africa: A historical and linguistic analysis', Nordic Journal of African Studies 10(3), 265-279.

Hanafy, M.I.B., 2016, 'Child neglect', in Encyclopedia of forensic and legal medicine, pp.482-490, viewed 14 May 2020, from https://www.sciencedirect.com/topics/ social-sciences/illegitimate-child.

Letsoela, M.P., 2015, 'A semantic analysis of Sesotho place names: Evidence from bus stop names', International Journal of English Language \& Translation Studies 3(1), 01-08.

Mabunda, P.N., 2012, 'An appraisal of naming patterns for schools with special reference to Dzumeri community in Mopani district, Limpopo', Master's thesis, School of Languages and Communication Studies, University of Limpopo, Polokwane. 
Mahwasane, M. \& Tshifaro, J.T., 2019, 'New-born baby naming practices of the Vhavenda: A sociolinguistic analysis perspective', South African Journal of African Languages 39(1), 175-184. https://doi.org/10.1080/02572117.2019.1618016

Matee, P.L., 2006, 'Origins and basis of Basotho names', Tsebo - Journal of Research and Creative Writing 1(1), 22-30.

Mbiti, J.S., 1990, African religion and philosophy, Heinemann Educational Books Inc, Portsmouth, $\mathrm{NH}$.

Mohome, P.M., 1972, 'Naming in Sesotho: Its sociocultural and linguistic basis', Names 20, 171-185. https://doi.org/10.1179/nam.1972.20.3.171

Mokhathi-Mbhele, M., 2006, 'Sesotho non-proprials as phrases', Tsebo - Journal of Research and Creative Writing 1(1), 31-42.

Mönnig, H.O., 1967, The pedi, Van Schaik, Pretoria

Neethling, B., 2005, Naming among the Xhosa of South Africa, The Edwn Mellen Press, Lewistone.

Possa, R. \& Khotso, P., 2015, 'Naming of Basotho medicinal plants: Semantic connection to their remedies', Southern African Journal for Folklore Studies 25(1) 34-47. https://doi.org/10.25159/1016-8427/541
Sengani, T.M., 2008, 'Strategic discourse in names: A critical discourse analytical interpretation with special reference to tshivenda naming practices', Unpublished PhD thesis, University of Limpopo, Polokwane.

Sengani, T.M., 2015, 'Emancipatory discourse in the names of children of the present generation: Some attempts of balancing power relations with special reference to Tshivenda naming practices', Literator 36(1), 1-10. https://doi.org/10.4102/lit. v36i1.10̂87

Setiloane, G., 1975, The image of god among the sotho-tswana, A.A. Balkema, Amsterdam.

Sogoba, M., 2019, The power of a name, viewed 25 February 2020, from https:// protect-za.mimecast.com/s/XUW3CKO7nQI6LM6oFkfx-P.

Thipa, H., 1984, 'What shall we call him?', South African Journal of African Languages $4(1), 84-99$.

Tullock, S., 1993, The reader's digest oxford complete wordfinder, The Reader's Digest Associated Limited, New York, NY.

Van Dijk, T.A., 2001, 'Principles of critical discourse analysis', in M.S. Wetherell \& S.J. Yates (eds.), Discourse theory and practice: A reader, pp. 300-317, Sage, London. 